\title{
WHAT DID WE JUST SEE? AMBIGUITY AND REVELATION IN THE EXTREME FIRST PERSON PLURAL
}

\author{
Hayley Scrivenor | University of Wollongong
}

\begin{abstract}
Questions of point of view are pivotal in fictional texts and determine what story, precisely, the author can tell. But what happens when writers present particularly challenging points of view? With a focus on the first person plural, this paper will interrogate stories where point of view 'asserts' itself to the reader. Using an approach informed by unnatural narratology, this paper addresses narrative situations where the make-up of a narrative collective is initially unclear, and where a challenging or ambiguous point of view is revealed to be an integral component of the plot.

In exploring the relationship between point of view, ambiguity and narrative revelation, this paper will consider a range of contemporary novels written predominately in the first person plural, notably TaraShea Nesbit's The Wives of Los Alamos, Malcolm Knox's The Wonder Lover and Jon McGregor's Even the Dogs. Highlighting the innate ambiguity of an 'extreme' first person plural allows us to consider ways in which authors of fiction in the first person plural have exploited this ambiguity to shape key revelations within their texts.
\end{abstract}

BIOGRAPHICAL NOTE

Hayley Scrivenor is a creative writing $\mathrm{PhD}$ candidate at the University of Wollongong. Her fiction and non-fiction has appeared in Seizure Online, SCUM, Mascara Literary Review, TEXT, Phantasmagoria Magazine, SWAMP and Verity La and she has been shortlisted for Overland's Story Wine Prize. Hayley is the Director of Wollongong Writers Festival, a literary festival held annually in November.

KEY WORDS

First person plural-Point of view-Ambiguity-Revelation-Unnatural narrative 
An 'extreme' first person plural-where 'we' is the predominate pronoun used in a text, and when it is used in a way that bends or breaks grammatical rules-lends itself to ambiguous narrative situations, where it is unclear exactly who is included in the narrating collective of a given text ${ }^{1}$. In narrative, ambiguity and revelation are invariably interlinked. The resolution of ambiguity, with its associated 'ah ha moment', brings change: in how either the characters or the reader experiences the reality of a piece of fiction. Linda Alcoff affirms that '[...] no embodied speaker can produce more than a partial account' (1992: 20). This assertion is complicated by the unusual practicalities of embodied but plural (and often omniscient) narrators found in unnatural first person plural narratives. In examining works in which extreme uses of the first person plural play on ambiguity, this paper seeks to enrich the ways we think about the role of point of view in crafting cohesive and satisfying narratives.

This paper looks at narrative situations wherein the make-up of the group that speaks is ambiguous in order to highlight how a challenging point of view is related to a key revelation within the text. I argue that, as writers, we can learn something from narratives where point of view is revealed to be an integral component of the plot. Drawing on strategies developed by the field of unnatural narratology and applying them in a framework tailored specifically to first person plural narratives, this paper hopes to equip creative writers and pedagogues to approach point of view in new ways.

\section{The first person plural}

Steven Millhauser has used the first person plural in a number of his short stories, including throughout the collections The Knife Thrower and Other Stories (1999) and We Others: New and Selected Short Stories (2011). He has said of the pronoun 'we', that it:

[...] didn't drag in its wake one hundred billion stories, as in the case of an 'I' or a 'he.' It strikes me as a barely explored pronoun, full of possibilities (Chénetier 2003).

Nigel Krauth, in the research background to 'Mediterranean Songs', a creative work that features the first person plural, notes that '[s]imilar to the "you" of second person narration, the narrating "we" is an unstable viewpoint that can disorient readers and lure them into perspectives not previously experienced' (2014). In Julio Cortázar's short story 'Axolotl' (1952) a young man obsessed with the axolotls at the aquarium in Paris's Jardin des Plantes finds himself on the inside of their tank. Or the narrators of the story are a group of axolotls who watch this man from their crowded glass prison; the reader is left to decide for themselves. Cortázar's short story does not use 'we' from the outset, but, when it does appear, it is so vital to the plot and serves the narrative so effectively that it would be altogether a different story without it.

This paper considers the particular challenges posed by the first person plural when it is used in novels. The effects of novelty, disorientation and ambiguity 
outlined above will clearly be amplified in longer works that contain an extreme first person plural. In Brit Bennet's The Mothers (2016), the narrating collective narrates only at intervals, and the majority of the book is told in the third person. And yet, this group of ageing women who are part of a dying African-American church in California are the means by which all the book's major revelations are delivered. They are simultaneously part of the community that drives the plot of the story, and a kind of Greek chorus that keeps the audience informed. In Justin Torres's We the Animals (2011) the narrator uses a first person plural that includes his two brothers until the point in the narrative where his sexuality is revealed to the reader. The reader re-contextualises the information they have received about the narratorwhose family has been established as being both violent and decidedly homophobic-in light of this new information. The shift from 'we' to 'I' speaks volumes about the narrator's future. In both books, there is a strange quality to the first person plural as it is used. The 'we' that narrates asks readers to reformulate their understanding of how embodied characters think and act 'in the real world'. The analysis offered here is concerned with extreme uses of the first person plural, where a strange or unnatural first person plural is developed throughout a novel. This paper approaches pronoun in the context of what a reader's assumptions may be upon 'entering' a work, but also what the extreme first person plural offers to the novel as a whole.

\section{Unnatural narratives}

This paper takes the approach that unnatural narratology-the study of narrative concerned with stories that break the contract with the reader, rejecting conventions about how people speak about and experience the world in 'naturalist' narrative forms, like realism-is the methodological approach that most effectively addresses extreme uses of the first person plural. Ann Jefferson notes that '[...] fiction articulates theory more interestingly and exhaustively than any explicitly theoretical writing' (1980: 7) and this paper uses three contemporary novels-Jon McGregor's Even the Dogs (2011), TaraShea Nesbit's The Wives of Los Alamos (2015) and Malcolm Knox's The Wonder Lover (2015) -to illustrate its central arguments. Monika Fludernik notes that 'the collective or group has been somewhat neglected in narrative research' (2009: 116). Holding up intentionally 'strange' and destabilising uses of the subject pronoun 'we' to the light allows us to see how they serve their narratives. Examining novels that embrace an unnatural first person plural also allows us to consider the role that ambiguity and revelation play in adding satisfying depth to a novel-length work.

\section{Natural narratives}

It is useful, at this juncture, to give an example of what unnatural narratologists would deem a 'natural we'. In Tadeusz Borowski's This Way for the Gas, Ladies and Gentlemen (Borowski 1992 [1959]) (first published in 
Polish, based on Borowski's own experiences as a political prisoner during the Second World War), 'we' is used to refer to all the inmates of the Auschwitz concentration camp where:

All of us walk around naked [...] [o]ur only strength is our great number

- the gas chambers cannot accommodate all of us (1992: 29).

While the first person plural in this situation is pervasive and sometimes ambiguous, and while it often exploits, in the words of Sunil Badami, the ironic possibilities of emphasising [...] de-individualisation' (2015), Borowski's 'we' is possible in a 'real world' setting. It is the result of the narrator being part of an actual collective, or series of collectives, that move through and experience this world in a way the reader could reasonably expect. This paper focuses on works that pull and stretch at what the first person plural can do, moving beyond these real-world boundaries in ways as different as the works themselves.

\section{Dogs, wives and wonders}

Brian Richardson contends that, from the twentieth century, the '[...] hitherto stable, intersubjective function [of the first person plural point of view in fiction] gives way to unreliable group sensibilities' (2006: 53). Even the Dogs (2011), The Wives of Los Alamos (2015) and The Wonder Lover (2015) bear out this theory. These novels were selected as case studies for this paper because they share a commitment to the extreme first person plural. In each, a group narrates in a way that subverts accepted notions of the individual, and how the first person plural should function in grammatically correct prose. Despite this commitment, there are important distinctions in their use of the first person plural point of view. In Jon McGregor's Even the Dogs (2011), we are introduced to the narrators as they watch police pick through the apartment of their friend who has died:

They don't see us, as we crowd and push around them. Of course they don't. How could they. But we're used to that. We've been used to that for a long time, even before. Before this (McGregor 2011: 4).

As Monika Fludernik points out, a 'narrator's gnomic statements serve to point out the general rules which help to explain events on the story level [...] they create a system of norms intended to make it easier for the reader to interpret the text' (2009: 27). The 'of course they don't' in the paragraph above serves to explain away why police don't register the presence of people crowding in on a crime scene without resolving the impossibility of the narrators' statement. The reader will eventually come to understand why a rag-tag group of addicts enjoy this level of access to a crime scene, but not until much later in the narrative. The narrators in TaraShea Nesbit's The Wives of Los Alamos (2015) also fail to observe the rules of the real world. The following quote highlights the cognitive challenge posed by the first person plural as Nesbit uses it: 
One day...we came downstairs to find our husbands smoking a pipe in their wingback chair, the orange one, an ugly thing we did not like, and we heard them ask us "How'd you like to live in the Southwest?" (Nesbit 2015: 4).

Given the context (a professionally published book, with the accompanying air of finality that a professionally produced book has) ${ }^{2}$ the reader is led to assume that these are not misprints, that although 'our husbands' is plural, there is only one orange wingback chair (which is 'an ugly thing'). For this sentence to meet the basic demands of logic and grammar, there must be multiple men (perhaps sharing one pipe) all sitting in one orange chair. Then the husbands (still plural) speak to 'us' (again, necessarily plural). The reader is left looking for an 'I' that the 'demands of ordinary usage' (Richardson 2015: 207) state should be easy to find. The Wives of Los Alamos is full of sentences like the following: 'Our husbands, the only cellist in town' (2015: 43). This is an example of a usage of the first person plural that Amit Marcus says 'point[s] to the absence of necessary connection between the grammatical form and its deictic function' (Marcus 2008: 1). In other words, it's a 'we' that does not work in the real world.

We turn from Nesbit's focus on the wives of men working on the Manhattan Project to a man with three wives on three different continents. Malcolm Knox's The Wonder Lover has at its heart the exploits of John Wonder. Wonder is a record verifier for a competitor of the Guinness Book of World Records. The reader learns from the narrators that the polygamous John Wonder has three homes, and three sets of children, and that all six of John Wonder's children:

[...] had our names, Adam [or] Evie. Adam Wonder and Evie Wonder. They attended, as we did, the free government school nearest the house. Our father and our mothers could not afford to be choosy. These children, Adam and Evie Wonder, are also us and we are they (Knox 2015: 19).

Here, we have sentences that actively encourage the reader to reformulate their understanding of how children, and indeed people, refer to themselves. A refusal in the text for the roles of Adam and Evie to remain fixed goes beyond the kind of confusion found in a classroom where two children happen to share the same name. This is exemplified in sentences like: 'He left us and went to us' (Knox 2015: 189). Richardson's definition of an unnatural narrative that 'conspicuously violates conventions of standard narrative forms' (2011: 34) applies here.

\section{Revelation}

But why do these texts break the contract with the reader about how people, how narrators, behave and speak? As Peter Brooks points out:

[...] we are able to read present moments - in literature and, by 
extension, in life - as endowed with narrative meaning only because we read them in anticipation of the structuring power of those endings that will retrospectively give them the order and significance of plot (1984:

94).

While the first part of this paper talked about the challenges that these collective narrators present to the reader, this second part considers the ways in which these challenges can serve their plots. When examining the revelations that lie at the heart of each of these plots, it is interesting to consider that each of the novels discussed here can be considered an example of ambiguity that is ultimately resolved ${ }^{3}$. The narrators of The Wives of Los Alamos are the only collective discussed as an example here where it is not possible, after carefully reading the text, to name each of the individual members, or even give a concrete number for how many people are in the narrating group. Membership of the group shifts throughout the narrative as certain women are singled out and described4. Nevertheless, the reader understands who the women are, and can articulate what has brought them together. In the case of The Wives of Los Alamos, the audience is aware (if not from their own historical knowledge of the Manhattan Project, then from contextual clues on the book jacket and introductory material) that the women's husbands are engaged in developing the atomic bomb. There is no 'twist' for the reader here. There is, however, a revelation to the collective in the book. Despite the varied nature of the experiences presented, one thing the wives do share is their lack of knowledge about what their husbands are working on:

We could not say fission, a word we overheard often when our husbands were graduate students. Our husbands said Gadget, and talked about issues with the Gadget, but what was the Gadget? We did not know (Nesbit 2015: 42).

The end of the book is characterised by the women's reassessment of their actions and the actions of their husbands in the light of new information:

Did we turn away from the clues because our questions would be met with silence? Or because in some deep way we did not want to know? (Nesbit 2015: 196).

The author has said, about The Wives of Los Alamos, that 'this novel, I hope, does not take a position, as much as complicate positions' (Nesbit and Sneed 2014). The point of view, where we cannot discern these dozens of women from each other, prepares the reader to understand the various responses of the women when they learn what they have been a part of building, and in doing so potentially complicates the reader's own response. Not only is the point of view in this instance integral to the plot of this novel, but the first person plural narration has an affinity with questions at the heart of the work around choice, responsibility, complicity and the legitimacy of the bombing of Hiroshima and Nagasaki. This strengthens the work's cohesiveness and ensures the challenges made to the reader by the text have been worthwhile. 
The key revelation of Even the Dogs comes in the penultimate chapter, when it is revealed that the entire narratorial collective have been dead for most, if not all, of the events described in the book. Although the reader is given clues throughout the narrative-indeed two of the dead narrators' bodies have been seen before the end of Chapter Two-it is only through the accumulation of ambiguous information, and the ultimate revelation of who the narrators are, that the meaning of certain passages becomes retrospectively clear. Of course, there will be those who have what Genette calls a 'narrative competence' (1980: 77 [italics in original]) that far outstrips my own. These people may read the following in the Even the Dogs and develop a theory about the narrators: 'We're used to it already, what's happened to him. What's happened to us... See here where the maggots have eaten his flesh' (McGregor 2011: 71). But the text leaves space for misunderstanding when it follows this passage with the line 'Get used to insects though, living like this. Flies, bedbugs, maggots. All sorts' (McGregor 2011: 72). This obfuscation, this playing on the ambiguous nature of the information given by the text, is key to the book's plot. With the revelation that everyone is dead, in the words of Jan Alber:

[...] we have to activate our knowledge about people who are alive (and able to tell stories) and our awareness of the fact that the dead cannot speak (2009: 90).

In the film The Usual Suspects (Singer 1995)-which turns on the question 'who is Keyser Söze?'-the story's ability to keep the audience guessing right up until (and possibly beyond) the ending owes itself largely to the possibility of keeping a man's face in shadow for the length of a short scene. It would be challenging to keep the collective ambiguous in a film version of Even the Dogs. The 'we' used by McGregor shelters this collective group of narrators, playing in to the key revelation of the text and deferring the 'dead giveaway' to the last possible moment.

The notion of revelation is pivotal to the climax of The Wonder Lover. The children (who narrate from a point in time after they have become aware of their father's betrayal) tell the story of how John Wonder acquired his three wives in a more or less linear fashion, in such a way that the children are consistently de-individualised ('he left us and came to us'). Towards the end of The Wonder Lover, the children describe themselves in detail for the first time, as in the following example:

Adam, the third Adam, Adam III, the son of Kim, suffered from muscular dystrophy. He spent a good deal of his early childhood in hospital. He was a good-natured little boy who pretended his trips to the hospital were adventures and rarely asked when he was going home (Knox 2015: 348).

It is this more gentle revelation that is, structurally, at the climax of the book. Learning the nature of the collective, coming to see the children as individuals and not as part of a group, is a major shift for the reader and the book's 
protagonist, John Wonder. The children tell him:

Father, we are not just The Children, we are ourselves, we are violent and hurt and hurtful human beings, yes, independent of what you are and were and of what you want from us [...] (Knox 2015: 351)

In Even the Dogs, the narrators are united by their shared and ongoing experiences of addiction, of feeling outside of civil society. In The Wonder Lover, the siblings are united not so much by blood (two out of the six children are not biologically John Wonder's children) but by the experience of having the same, largely absent, father. The Wives of Los Alamos, too, is defined by the plurality of the experiences it portrays. As Alber points out ' $[\mathrm{m}]$ any narratives urge us to develop new frames of reading before we can formulate hypotheses about their potential messages' (2009: 93). What Nesbit does most successfully is encourage her reader to erase the line between individuals. In The Wives of Los Alamos, each woman's experience is simultaneously only hers and shared by the collective and then, through the act of reading, by the reader. What Richardson calls 'the instabilities that flavor nearly all "we" narration' (Richardson 2006: 53) are evident in all three works, even if in each case the plural nature of the narrators plays out in different ways. In each case, the position/s of the narrator are central to the plot. In each case, the sometimes-challenging point of view, ambiguity and revelation have an important relationship with each other and contribute to a unified narrative experience for the reader.

\section{Conclusion}

Alber sees the 'unnatural' in fiction as undergoing a constant process of familiarisation. He argues that as techniques become more prevalent and lose their disrupting quality they determine the development of literature itself (see Alber et al, 2013). Each of these novels has been shaped by the use of the first person plural. It is useful for creative writers to think about the ways that not only the first person plural, but also ambiguity and revelation, play out in texts. In the future, there is scope to expand the analysis presented here to further study of the category of unresolved or 'radical' ambiguity in fiction that uses an extreme first person plural. There is also exciting work to be done on extreme first person plural narratives where, for example, the relationship between the teller and the told is ambiguous. In highlighting the relationship between point of view and specific revelations in the text, this paper has proposed that these novels in the first person plural give us a cohesive and satisfying model for a work of fiction. In highlighting 'we' narratives that push their story model to its limits, I have explored the work of authors using 'we' because it gives their narrative something it may not get any other way. It may be that as more extreme first person plural narratives are written, the 'unnaturalness' of a text, and hence the challenge posed to the reader will lessen. In focussing on pronoun use, however, and in considering these novels as more than the sum of their parts, this paper has sought to highlight existing 
work in the first person plural and to showcase what can be gained by challenging the reader in this way.

\section{Acknowledgements}

This article was written with the support of an Australian Government Research Training Program Scholarship.

\section{Endnotes}

1. Although he does not define the term in the work itself, I borrow 'extreme' from Brian Richardson, who employs it in his Unnatural Voices: Extreme Narration in Modern and Contemporary Fiction (2006), a work that has also been influential in my use of the term 'challenge' (as in the term 'challenge to the reader') when discussing disruptive narrative techniques throughout this paper.

2. What Genette would call the paratext, namely 'the complex mediation between book, author, publisher, and reader: titles, forewords, epigraphs, and publishers' jacket copy [that] are part of a book's private and public history' (Richard Macksey in Genette 1997: xi) that inform the reader's experience of, and attitude towards, a text.

3. I wish to thank Rebekah Clarkson for her useful comments on this paper when it was first presented on the final day of the AAWP conference in 2017. I unfortunately do not have the space here to further explore the notion of resolved or unresolved (what some would call 'radical') ambiguity. I do consider it to be a useful category for approaching unnatural uses of the first person plural and one that that is already beginning to inform my subsequent research.

4. This is reminiscent of Joan Chase's novel During the Reign of the Queen of Persia (1983), which is narrated in the first person plural by the four female grandchildren of a forbidding matriarch in rural Ohio. Anytime one of the four narrators is singled out-described speaking or performing an action-the third person is used. As each of the four narrators is discussed in this way at some point in the narrative, it is clear there is no one left to serve as the novel's consistent 'first-person', disappointing the reader's 'expectation that this "we" will dissolve into one "I"' (Morris 1992: 20). 


\section{Works Cited}

Alber, Jan 2009 'Impossible Storyworlds-and What to Do with Them' StoryWorlds: A Journal of Narrative Studies 1 (1), 79 - 96

Alber, Jan, Stefan Iverson, Henrik Skov Nielsen, and Brian Richardson 2012 'What is Unnatural about Unnatural Narratology? A Response to Monika Fludernik' Narrative, 20 (3), $371-382$

Alcoff, Linda 1992 'The Problem of Speaking for Others' Cultural Critique 7 (20), 5 32

Badami, Sunil 2015 'Thrice hitched to allegory: The Wonder Lover by Malcolm Knox' Sydney Review of Books 25 August, at https://sydneyreviewofbooks.com/the-wonder-lover-malcolm-knox/ (accessed 4 January 2018)

Bennet, Brit 2016 The Mothers New York: Riverhead Books

Borowski, Tadeusz 1992 [1959] This Way For The Gas, Ladies And Gentlemen London: Penguin

Brooks, Peter 1984 Reading for the Plot: Design and Intention in Narrative Cambridge: Harvard University Press

Chase, Joan 1983 During the Reign of the Queen of Persia New York: Harper \& Row

Chénetier, Marc 2003 ‘An Interview with Steven Millhauser’ Transatlantica, vol. 1.

Cortázar, Julio 2010 [1952] “Axolotl', Southern Cross Review December, at http://southerncrossreview.org/73/axolotl.html (accessed 18 April 2018)

Fludernik, Monika 2009 An Introduction to Narratology London: Routledge

Genette, Gérard 1980 Narrative Discourse: An Essay in Method trans. JE Lewin Ithaca: Cornell University Press

Genette, Gérard 1997 Paratexts: Thresholds of Interpretation trans. JE Lewin New York: Cambridge University Press

Knox, Malcolm 2015 The Wonder Lover Sydney: Allen \& Unwin

Krauth, Nigel 2014 'Mediterranean songs' TEXT Special Issue 27, Creative Writing as Research III October, at http://www.textjournal.com.au/speciss/issue27/Krauth.pdf (accessed 18 April 2018)

Marcus, Amit 2008 'We are you: The plural and the dual in "we" fictional narratives' Journal of Literary Semantics 37 (1), 1 - 21

McGregor, Jon 2011 Even the Dogs London: Bloomsbury

Millhauser, Steven 1999 The Knife Thrower and Other Stories New York: Random House

Millhauser, Steven 2011 We Others: New and Selected Stories New York: Alfred A. Knopf 
Morris, Adaleide 1992 'First Persons Plural in Contemporary Feminist Fiction’ Tulsa Studies in Women's Literature 11 (1), $11-29$

Nesbit, TaraShea 2015 The Wives of Los Alamos London: Bloomsbury

Nesbit, TaraShea and Christine Sneed 2014 'Q And A with TaraShea Nesbit, Author of the Novel The Wives Of Los Alamos' Christine Sneed 27 May, at http://www.christinesneed.com/blog/2014/5/27/q-and-a-with-tarasheanesbit-author-of-the-novel-the-wives-o.html (accessed 31 July 2016)

Richardson, Brian 2006 Unnatural Voices: Extreme Narration in Modern and Contemporary Fiction Columbus: The Ohio State UP

Richardson, Brian 2015 'Representing Social Minds: "We" and "They" Narratives, Natural and Unnatural' Narrative 23 (2), 200 - 12

Singer, Bryan 1995 The Usual Suspects USA, distributed by Metro-Goldwyn-Mayer Torres, Justin 2011 We the Animals London: Granta 